\title{
Factors Associated with Anemia among Pregnant Women in Trimester III
}

\author{
Katmini'), Astri Yunita²) \\ ${ }^{1)}$ Masters Program in Public Health, IIK Strada Indonesia \\ 2)Diploma III in Midwifery, School of Health Sciences Bhakti Mulia Kediri
}

\section{ABSTRACT}

Background: The estimated anemia prevalences among pregnant women are Asia 48.2\%, Africa 57.1\%, America 24.1\% and Europe 25.1\%. $40 \%$ of maternal deaths in developing countries is associated with anemia during pregnancy. Adverse impacts of anemia in pregnancy toward fetus in developing countries is higher, whereas in industrial countries, perinatal prognosis is not associated with anemia in pregnancy. Anemia in TM III gives effects to the incidence of Low Birth Weight and preterm labour. The study aims to find out factors associated with anemia incidences among pregnant women in TM III in Community Health Center (Puskesmas) Pesantren I, the city of Kediri.

Subjects and Method: It was a cross sectional study conducted in Puskesmas Pesantren I the city of Kediri. There were 30 pregnant women of TM III. The dependent variable was anemia. The independent variables were age, education, occupation, parity, and the compliance in consuming iron tablet. The data were collected by questionnaire. The data were analyzed by Chi square.
Results: Low education $(\mathrm{OR}=9.33$; $95 \% \mathrm{CI}=$ 1.51 to $5.76 ; \mathrm{p}=0.010)$, work at home $(\mathrm{OR}=8.66$; $95 \% \mathrm{CI}=3.46$ to $21.65 ; \mathrm{p}<0.001$ ), multiparous $(\mathrm{OR}=13.20 ; 95 \% \mathrm{CI}=2.11$ to $8.25 ; \mathrm{p}=0.003)$, and did not adhere to iron tablet consumption $(\mathrm{OR}=$ $5.50 ; 95 \% \mathrm{CI}=1.14$ to $2.64 ; \mathrm{p}=0.028$ ) increased the risk of anemia. Age 20-35 years old $(\mathrm{OR}=$ $0.35 ; 95 \% \mathrm{CI}=0.15$ to $0.80 ; \mathrm{p}=0.012)$ reduced the risk of anemia.

Conclusion: Low education, work at home, multiparous, and did not adhere to iron tablet consumption increase the risk of anemia. Age 2035 years old reduces the risk of anemia.

Keywords: anemia, iron tablet

\section{Correspondence:}

Katmini. Masters Program in Public Health, IIK Strada. Jl. Manila 37 Sumberece Tosaren Pesantren, Kediri, East Java, Indonesia. Email: katminitini@gmail.com. Mobile: +6282334662921.

\section{Cite this as:}

Katmini, Astri Y (2020). Factors Associated with Anemia among Pregnant Women in Trimester III. J Matern Child Health. 05(03): 313-320. https://doi.org/10.26911/thejmch.2020.05.03.10.

(c) (i) (-) Journal of Maternal and Child Health is licensed under a Creative Commons Attribution-Non Commercial-Share Alike 4.o International License.

\section{BACKGROUND}

Anemia is a global public health problem that may increase morbidity and mortality rate. Anemia prevalence rate is still high, it is proven by World Health Organization Data (Bricker, 2014; WHO, 2018), that globally the worldwide prevalence of anemia in pregnancy is $41.8 \%$. Asia's prevalence of anemia in pregnancy is $48.2 \%$, Afrika's is $57.1 \%$, America's is 24.1\% and Europe's is 25.1\%. In developing countries there is around $40 \%$ of maternal death associated with anemia in pregnancy (Santoso, 2009; Anggraini, 2014). Anemia is a condition where the number and size of red blood cells or hemoglobin concentration is below normal limit, as the result it may disturb blood capacity in delivering oxygen to the entire body (Berks et al., 2013). Anemia among pregnant women is closely related to maternal and child mortality and morbidity, including the risk of miscarriage, stillbirth, prematurity and low birth 
Katmini et al. / Factors Associated with Anemia among Pregnant Women

weight (WHO, 2018; Berks et al., 2013).

Based on the Data (Riskesdas, 2018) the percentage of anemic pregnant women is increased compares to the result of Riskesdas year 2013 which is $37.1 \%$. From the data of 2018, the majority of anemic pregnant women are at the age of $15-24$ years old that is $84.6 \%$, age $25-34$ years old that is $33.7 \%$, age $35-44$ years old that is $33.6 \%$, and age $45-54$ years old that is $24 \%$. Meanwhile the data of women of reproductive age who suffer from chronic energy deficiency quite the contrary indicate positive trend compare to the previous year. The proportion of chronic energy deficiency among women of reproductive age descended, compares to of that 2013. It is from $24.2 \%$ for women of reproductive age who were pregnant in 2013 into $17.3 \%$ in 2018. Furthermore, for women of reproductive age who were not pregnant, it was $20.8 \%$ in 2013 descended into 14.5\% in 2018.

Anemia prevalence and risk of chronic energy deficiency among the women of reproductive age greatly affect a child's health condition at birth. Both matters are included as things which potentially trigger the occurrence of stunting among children seen from birth weight and length (Dewi, 2011). The ideal proportion of birth weight is not less than 2500 gram and birth length is not less than $48 \mathrm{~cm}$. Based on Riskesdas 2018, the proportion of babies with birth weight less than 2500 gram on children of o -59 months old reaches $6.2 \%$. The figure has exceeded the target of national medium term development plan 2019 which is targetted descending up to $8 \%$. However, to be noticed that the figure of $6.2 \%$ is obtained from $56.6 \%$ infant of $0-59$ months old who have maternal and child health book (Riskesdas, 2018).

Data of Riskesda also indicates that infants with birth weight proportion between 2500-3999 gram have reached 90.1\%. Meanwhile, data of infants with ideal birth length, which is $48 \mathrm{~cm}$, slightly increased compared to of that five years ago. It was $20.2 \%$ in $20-$ 13 , increased to $22.7 \%$ in 2018 . If we trace again the growth period from birth up to five years old of age, the stunting rate and nutritional status of very short and short descend from $37.2 \%$ in 2013, into $30.8 \%$ in 2018 (Riskesdas, 2018).

Anemia in pregnancy is defined as hemoglobin concentration $(\mathrm{Hb})<11,0 \mathrm{~g} / \mathrm{l}$, anemia affects more than 56 million women around the world, two third of them come from Asia (Goonewardene et al., 2012). Anemia affects almost two third of pregnant women in developing countries and contribute to both maternal as well as fetal mortality. The results of pregnancy with anemia are intrauterine growth retardation (IUGR), premature birth, low birth weight, increased risk of neonates death (Ansari et al., 2016). Based on a survey conducted in Puskesmas Pesantren I, the city of Kediri, in 2018 there were 40 pregnant women who suffered from anemia incidences.

Data from Health Office of East Java Province year 2018 states that the number of pregnant women who suffered from anemia is $56 \%$ of all existing pregnancy. The data from Health Office of Kediri Regency year 2018 reveals that anemia prevalence among pregnant women is $37.1 \%$ (Depkes RI, 2014; Dinkes Jatim 2018; Kemenkes RI, 2015).

There were 59 pregnant women with anemia based on the data of in Puskesmas Pesantren I the city of Kediri year 2018. Some of them suffer from anemia because they were reluctant to comsume iron tablet given. They refused it because it made them felt nausea or because they hate taking medicine (Depkes RI, 2014; Dinkes Jatim 2018; Kemenkes RI, 2015).

The study aims to discover factors associated with anemia incidences among pregnant women in TM III in Puskesmas Pesantren I the city of Kediri. 
Katmini et al. / Factors Associated with Anemia among Pregnant Women

\section{SUBJECTS AND METHOD}

\section{Study Design}

It was a quantitative study with cross sectional study design.

\section{Population and Sample}

The sample was 30 pregnant women in TM III from Puskesmas Pesantren I the city of Kediri.

\section{Study Variables}

The independent variables to be studied were age, education, occupation, parity, and compliance of iron tablet consumption. The dependent variable was anemia incidences.

\section{Operational Definition of Variables} Maternal age was defined as a number in the form of figures that state the physical. It was measured by using questionnaires with the categories of high risk age $(<20$ years or $>35$ years) and low risk age (20-35 years).

Level of education was defined as pregnant women's level of knowledge observed from level of education. It was measured by using questionnaires with the categories of high level of education ( $\geq$ Senior high school) and low level of education $(<$ Senior high school).

Occupation was defined as activities conducted by pregnant women to obtain income or meet daily needs. It is measured by using questionnaires with the categories of employed and unemployed.

Parity was defined as the number of live births a woman has ever had. It was measured by using questionnaire, with the categories of primigravida and multigravida.

Compliance in taking iron supplement tablet was defined as pregnant women's compliance in taking iron supplement tablet given by health workers. It was measured by using questionnaires with the categories obey and disobey.

Anemia incidences among pregnant women in TM III was defined as a condition where pregnant women experience descend $\mathrm{Hb}$ level in the blood that was less than
$11 \mathrm{gr} / \mathrm{dl}$. It was measured by using questionnaires with the categories of anemic and nonanemic.

\section{Study Instruments}

Primary data was collected by using interview with questionnaires and supported by secondary data.

\section{Data Analysis}

The data analysis used was Bivariate Analysis with Chi Square by using SPSS 22.

\section{Research Ethics}

The study was conducted in accordance with study ethics, informed consent, anonymity, confidentiality. Ethical approval of the study was obtained from Health Research Ethics Committee of Dr. Moewardi Regional Hospital, Surakarta, Central Java, Indonesia, No. 417/UN27.6/KEPK/2019.

\section{RESULTS}

\section{Sample Characteristics}

Study subject characteristics describe the distribution of each variable. The result ofstudy subject characteristics in table 1 indicates that the 30 study subjects have different distributions. Study variables decriptions was elaborated based on characteristics, criteria, and percentage (\%).

The comparisson of study subjects with almost similar number of incidences were pregnant women with anemia as many as 14 respondents (46.7\%) and pregnant women with no anemia as many as 16 respondents (53.3\%). Most pregnant women aged 20-35 years, that was 25 mothers (83.3\%), had higher level of education than higher, that was 20 mothers (66.7\%), worked as housewife, that was 15 respondents (50\%), had been pregnant more than once (multigravida), that was 17 mothers (56.7\%) and had similar level of compliance between obey and disobey categories, that was 1:1 (50\%).

\section{The result of bivariate analysis}

Study variables namely pregnant women, level of education, occupational status, parity, 
Katmini et al. / Factors Associated with Anemia among Pregnant Women

compliance, and anemia. Bivariate analysis test used was Chi Square test. Table 2 indicates the result of association between independent variables and dependent variable. From the result of bivariate test by using chi square test it obtained a correlation between maternal age $(\mathrm{OR}=0.35 ; 95 \% \mathrm{CI}=0.15$ to $0.80 ; p=0.012)$, level of education $(\mathrm{OR}=$ -
9.33; $95 \% \mathrm{CI}=1.51$ to $5.76 ; \mathrm{p}=0.010)$, occupation $(\mathrm{OR}=8.66 ; 95 \% \mathrm{CI}=3.46$ to 21.65 ; $\mathrm{p}<0.001)$, parity $(\mathrm{OR}=13.20 ; 95 \% \mathrm{CI}=02.11$ to $8.25 ; \mathrm{p}=0.003)$, and compliance $\left(\mathrm{OR}=5\right.$ - $^{-}$ $50 ; 95 \% \mathrm{CI}=1.14$ to $2.64 ; \mathrm{p}=0.028$ ) with anemia incidences among pregnant women in TM III.

Table 1. Sample Characteristics

\begin{tabular}{llcc}
\hline \multicolumn{1}{c}{ Variables } & \multicolumn{1}{c}{ Criteria } & Frequency & Percentage (\%) \\
\hline Maternal Age & < 20 years / > 35 years & 5 & 16.7 \\
Level of Education & 20 - 35 years & 25 & 83.3 \\
& < High School & 10 & 33.3 \\
Occupation & 2 High School & 20 & 66.7 \\
& Laborer & 4 & 13.3 \\
& Farm worker & 1 & 3.3 \\
& Farmer & 2 & 6.7 \\
Parity & Housewife & 15 & 50.0 \\
Compliance & Private employee & 8 & 26.7 \\
& Multigravida & 17 & 56.7 \\
Anemia Incidences & Primigravida & 13 & 43.3 \\
& Obey & 15 & 50.0 \\
& Disobey & 15 & 50.0 \\
& Anemic & 14 & 46.7 \\
& Non Anemic & 16 & 53.3
\end{tabular}

Table 2 The Result of Bivariate Analysis on Factors that Associated with Anemia Incidences among Pregnant Women in TM III

\begin{tabular}{|c|c|c|c|c|c|c|c|c|}
\hline \multirow{3}{*}{ Independent Variables } & \multicolumn{4}{|c|}{ Anemia Incidences } & \multirow{3}{*}{$\mathbf{O R}$} & \multicolumn{2}{|c|}{$95 \% \mathrm{CI}$} & \multirow{3}{*}{$\mathbf{p}$} \\
\hline & \multicolumn{2}{|c|}{ Anemic } & \multicolumn{2}{|c|}{$\begin{array}{c}\text { Non } \\
\text { Anemic }\end{array}$} & & \multirow{2}{*}{$\begin{array}{l}\text { Upper } \\
\text { Limit }\end{array}$} & \multirow{2}{*}{$\begin{array}{l}\text { Lower } \\
\text { Limit }\end{array}$} & \\
\hline & $\mathbf{n}$ & $\%$ & $\mathbf{n}$ & $\%$ & & & & \\
\hline \multicolumn{9}{|l|}{ Maternal Age } \\
\hline $\begin{array}{l}\text { High risk ( }<20 \text { or } \geq 35 \\
\text { years) }\end{array}$ & 8 & 26.7 & 7 & $23 \cdot 3$ & \multirow[t]{2}{*}{8.66} & \multirow[t]{2}{*}{3.46} & \multirow[t]{2}{*}{21.65} & \multirow[t]{2}{*}{$<0.001$} \\
\hline $\begin{array}{l}\text { Low risk (20-35 years) } \\
\text { Level of Education }\end{array}$ & 3 & 10 & 12 & 40 & & & & \\
\hline $\begin{array}{l}\geq \text { Senior high school } \\
<\text { Senior high school }\end{array}$ & $\begin{array}{l}6 \\
8\end{array}$ & $\begin{array}{c}20 \\
26.7\end{array}$ & $\begin{array}{c}14 \\
2\end{array}$ & $\begin{array}{l}46.7 \\
6.7\end{array}$ & \multirow[t]{2}{*}{9.33} & \multirow[t]{2}{*}{1.51} & \multirow[t]{2}{*}{$5 \cdot 76$} & \multirow[t]{2}{*}{0.010} \\
\hline Occupational Status & & & & & & & & \\
\hline $\begin{array}{l}\text { Employed } \\
\text { Unemployed }\end{array}$ & $\begin{array}{l}8 \\
8\end{array}$ & $\begin{array}{l}26.7 \\
26.7\end{array}$ & $\begin{array}{c}12 \\
2\end{array}$ & $\begin{array}{l}40 \\
6.7\end{array}$ & \multirow[t]{2}{*}{0.35} & \multirow[t]{2}{*}{0.15} & \multirow[t]{2}{*}{0.80} & \multirow[t]{2}{*}{0.012} \\
\hline Parity & & & & & & & & \\
\hline $\begin{array}{l}\text { Primigravida } \\
\text { Multigravida }\end{array}$ & $\begin{array}{c}2 \\
12\end{array}$ & $\begin{array}{l}6.7 \\
40\end{array}$ & $\begin{array}{c}11 \\
5\end{array}$ & $\begin{array}{l}36.7 \\
16.7\end{array}$ & \multirow[t]{2}{*}{13.20} & \multirow[t]{2}{*}{2.11} & \multirow[t]{2}{*}{8.25} & \multirow[t]{2}{*}{0.003} \\
\hline Compliance & & & & & & & & \\
\hline Obey & 4 & $13 \cdot 3$ & 11 & 36.7 & \multirow[t]{2}{*}{$5 \cdot 50$} & \multirow[t]{2}{*}{1.14} & \multirow[t]{2}{*}{2.64} & \multirow[t]{2}{*}{0.028} \\
\hline Disobey & 10 & $33 \cdot 3$ & 5 & 16.7 & & & & \\
\hline
\end{tabular}


Katmini et al. / Factors Associated with Anemia among Pregnant Women

\section{DISCUSSION}

1. Association Between Maternal Age and Anemia Incidences

An individual age is determined from the moment they were born up to the moment of their birthday. The older the person, the more mature and the stronger the person will be in thinking and working (Berks et al., 2007; Edouard et al., 2013). The older the person, the more mature she will think hence she will be more motivated in examining her pregnancy to prevent complication. High risk age ( $<20$ years or $\geq 35$ years), refers to younger pregnant women and older pregnant women, pregnant women who aged $<20$ years old mostly lack of information about ANC, that they ignore the ANC visit (Varney, 2015). In addition, pregnant women who aged >35 years have started getting understand about the first pregnancy (Brown et al., 2014).

2. Association between Occupational Status and Anemia Incidences

Pregnant women with high knowledge about pregnancy checkup contribute in accomplishing the target of pregnancy checkup visits. Pregnant women can obtain the knowledge about pregnancy checkups from the previous experience or from families' and neighbors' experience. Pregnant women's knowledge about pregnancy checkups may get affected by several factors among others are educational level, social economy, environment and internal factor of pregnant women (Awalia et al., 2010). The knowledge can be improve with various ways namely counseling or individual approach by skilled cadres. However not all pregnant women are ready to conduct a counseling about the importance of pregnancy checkups (Cunningham, 1995).

Someone with no knowledge about the importance of pregnancy checkups, most likely will face problems and complications that may lead to maternal and infant morbidity and mortality. Therefore, maternal knowledge is very important to support maternal and fetal health during pregnancy (Paendong et al., 2016).

\section{Association of Occupational Status and Anemia Incidences}

Experience does not always come as something that is personally gone through by oneself, it may start from something heard or seen (Achmadi, 2013). While they are listening, sometimes there are words that suggest ANC is important yet it does not matter if they do not do it, just like the person's wife undergo. It may affect the knowledge obtained will not be executed into behavior (Efiong and Banjoko, 1975).

The level of capability to meet the needs is varied. In term of social economy, those from high level of social economy are likely to always learn and implement it. Whereas those who come from low social economy, even if they have good knowledge they will feel inferior to bring their wife for ANC visits when they do not have any money (Dewi, 2011). Distance and transportation greatly affect one's behavior, even if they have good knowledge, their motivation will be weaken, and canceling their ANC visit and other factors that are able to obstruct ANC behavior (Khaing et al., 2012; Butler et al., 2014; Koster et al., 2016).

\section{Association between parity and ane- mia incidences}

Parity is a risk factor in determining maternal health status during pregnancy and childbirth. Women who experience pregnancy and childbirth for the first time, it will increase the emerging health risks since they have never experienced pregnancy before and just start to open the birth canal (Lestrina et al., 2015; Supariasa, 2015). Women who have given birth before consider themselves to be experienced and take the pregnancy as something ordinary (Cunningham, 1995). However, giving birth too often will weaken ute- 
rus because of the scar tissue. Weak scar tissue will lead to inadequate blood supply to placenta that impact to the obstructed nutrition distribution from mother to fetus and it results in the disruption to fetal growth.

According to the previous researcher there is a significant association between parity and anemia during pregnancy, furthermore the study conveys that the more often a woman experience pregnancy, the more she lose blood, and suffer from anemia (Paendong et al., 2016).

\section{Association between compliance and Anemia Incidences}

Compliance in taking iron supplement table measured from the accuracy of the number of tablet to be taken, the accuracy in consuming iron supplement tablet, frequency of consuming each day. Iron supplementation or the administration of iron supplement tablet is one of the important efforts in preventing and overcoming anemia, especially iron deficiency anemia. Iron supplementation is an effective way since the composition of iron is equipped with folic acid that simultaneously may prevent folic acid deficiency anemia (Afnita, 2014).

The result of the study is in line with a study by Rahayu (Rahayu, 2010; Septadara, 2018) that there is an association between compliance to consume iron supplement tablet and $\mathrm{Hb}$ level. The more comply in taking the iron supplement tablet the higher $\mathrm{Hb}$ level of pregnant women.

Among pregnant women in TM III came to Puskesmas Pesantren I the city of Kediri there were factors that affect iron supplement tablet consumption namely lack of understanding of the table they get, they felt nausea and vomitted. Their average education mostly was high school graduates that they lacked experience over the importance of iron supplement tablet, the lack of awareness toward the threat of anemia for pregnant women and infants, and the occurence of side effect (nausea and headache) that appeared after taking iron supplement tablet (Shahrawat et al., 2014).

Conclusion of the result of the study is there is an association between maternal age, level of education, occupation, parity and compliance of pregnant women in TM III and anemia incidences. It should be noticed that pregnant women should be more attentive to their pregnancy and regularly go for pregnancy check ups in healthcare facilities. To reduce the rate of anemia incidences during pregnancy counseling can be given about the importance of anemia prevention during pregnancy by improving Nutrition intake and the adminsitration of iron (Fe) supplement tablet.

\section{AUTHOR CONTRIBUTION}

Katmini conducted the study and prepared the equipments for the study. Astri Yunita compiled, described and process the data, and prepared the article and discussion needed for equipments of the study.

\section{CONFLICT OF INTEREST}

There was no conflict of interest.

FUNDING AND SPONSORSHIP

The study was funded by the fund provided by IIK Strada Indonesia and STIKes Bhakti Mulia, Kediri.

\section{ACKNOWLEDGEMENT}

The researchers would like to give their gratitude to IIK Strada Indonesia and STIKes Bhakti Mulia Kediri for the support in conducting the study.

\section{REFERENCE}

Achmadi UF (2013). Kesehatan Masyarakat Teori dan Aplikasi. Jakarta: Raja Grafindo Persada.

Anggraini Y (2014). Hubungan faktor yang menyebabkan anemia pada ibu hamil 
Katmini et al. / Factors Associated with Anemia among Pregnant Women

di wilayah kerja Puskesmas Guguak Panjang Kota Bukittinggi. Bidan Prada. Retrieved from http://ojs.akbidylpp.ac.id/index.php/Prada/article/view/306/218

Ansari R, Azwar (2016). Tingkat pengetahuan mahasiswa tentang anemia. Yogyakarta: Pustaka Pelajar.

Awalia, Neneng, and Sukaisih (2010). Kejadian anemia pada ibu hamil. Universitas Aisiyah Yogyakarta.

Berks D, Hoedjes M, Raat H, Duvekot JJ, Steegers EA, Habbemma JD (2013). Risk of cardiovascular disease after preeclampsia and the effect of lifestyle interventions: A literature-based study. NCBI US National Library of Medicine National Institutes of Health. Retrieved from https://doi.org/10.1111/1471-0528.12191.

Bricker L (2014). Optimal antenatal care for twin and triplet pregnancy: The evidence base. Journal Best Practice and Research Clinical Obstetrics and Gynecology. 28(2):305-17. https://doi.org/10.1016/j.bpobgyn.2013.12.006.

Brown SJ, Sutherland GA, Gunn JM, Yelland JS (2014). Changing models of public antenatal care in Australia: Is current practice meeting the needs of vulnerable populations? Midwifery. 30(3): 303-9. https://doi.org/10.1016/j.midw.2013.10.018.

Butler MM, Brosnan MC, Drennan J, Feeney $\mathrm{P}$, Gavigan O, Kingston M, O'Brien D, Sheehy L, Walsh MC. (2014). Evaluating midwifery-led antenatal care: Using a programme logic model to identify relevant outcomes. Midwifery. 30(1): e34-41. https://doi.org/10.1016/j.midw.2013.10.003

Cunningham FG (1995). William obstetrics. Edition 20. Jakarta: EGC

D Berks, Hoedjes M, Raat H, Duvekot JJ, Steegers EA, Habbema JD (2007). Risk of cardiovascular disease after preeclampsia and the effect of lifestyle interventions: A literature - based study. BJOG. 120(8):924-31. https://doi.org/10.1111/1471-0528.12191.

Departemen Kesehatan Republik Indonesia (2014). Data Anemia di Indonesia. Retrieved from http://www.depkes.go.id/resources/download/pusdatin/profilkesehatan-indonesia/profil-kesehatanindonesia-2014.pdf

Dewi S (2011). Asuhan Kehamilan untuk Kebidanan. Jakarta: Salemba Medika.

Dinas Kesehatan Provinsi Jawa Timur (2018). Data Anemia di Provinsi Jawa Timur. Retrieved from https://dinkes.ja-

timprov.go.id/userfile/dokumen/BUK U\%20PROFIL\%2OKESEHATAN\%2OJ ATIM\%202018.pdf

Edouard L, Vassilis T, Francois G, Dominique C, Baha S, Bassam H(2013). Risk Factor of supperimposed preeclampsia in women with essential chorinc hypertensional treated before pregnancy. May. Plos One. 8 (5): eG2140. https://doi.org/10.1371/journal.pohe.0062140.

Efiong EI, Banjoko MO. (1975). The obstetric performance of Nigerian primigravidae aged 16 and under. Br J Obstet Gynaecol, 82(3):228-33. Br J Obstet Gynaecol. https://doi.org/10.1111/j.1471-0528.1975.tboo625.x.

Goonewardene M, Shehata M, Hamad A (2012). Anemia in pregnancy Best Practice And Best Pract Res Clin Obstet Gynaecol. 26(1): 3-24. https://doi.org/10.1016/j.bpobgyn.2011.10.010.

Kemenkes RI (2015). Data Anemia di Indonesia. Retrieved from http://www.depkes.go.id/resources/download/pusdati n/profil-kesehatan-indonesia/profilkesehatan-indonesia-2014.pdf.

Khaing ZL, Win LL, Mon MM, Soe K, Sein TT (2012). Knowledge on danger signs and 
Katmini et al. / Factors Associated with Anemia among Pregnant Women

antenatal care visits made by third trimester pregnant women in Shwepyitha Township. Myanmar Health Sciences Research Journal. 24(2). Retrieved from https://www.dmr.gov.mm/publication/MHSRJ/MHSRJ\%20Vol\%2024\%202012/Vol\%2024\%20No.\%202\%20(2012).pdf.

Koster W, Ondoa P, Sarr AM, Sow AI, Schultsz C, Sakande J, Diallo S, Pool R (2016). Barriers to uptake of antenatal maternal screening tests in Senegal. Journal SSM-Population Health, 2: 784792.https://doi.org/10.1016/j.ssmph.2016.10.003.

Lestrina D, Nurhayati I, Martony O (2015). Pengaruh promosi kesehatan terhadap peningkatan pengetahuan dan kadar hemoglobin pada wanita usia subur di Desa Paluh Kemiri Kecamatan Lubuk Pakam. Wahana Inov. Retrieved from http://penelitian.uisu.ac.id/wp-content/uploads/2017/05/10.-Dini-Lestrinadkk.pdf

Paendong FT, Suparman E, Tendean HMM (2016). Profil Zat Besi (Fe) pada ibu Hamil dengan Anemia di Puskesmas Bahu Manado. J e-Clinic, 4(1). https://doi.org/10.3579o/ecl.4.1.2016.10985.

Riset Kesehatan Dasar (2018). Kejadian Anemia di Indonesia. Retrieved from https://www.kemkes.go.id/resources/dow nload/info-terkini/hasil-riskesdas-2018.pdf.
Santoso (2009). Faktor - Faktor Yang Berhubungan Dengan Kehamilan Pada Ibu Hamil Di Kota Metro. Jurnal Kesehatan Metro Sai Wawai, 2(1). Retrieved from http://isjd.pdii.lipi.go.id/admin-jurnal/2109110.pdf.

Septadara UL (2018). Hubungan kepatuhan mengkonsumsi tablet Fe dengan kejadian anemia pada ibu hamil trimester III di Puskesmas Mlati 1 Sleman Yogyakarta. Publikasi Hasil Penelitian. Universitas Aisyiyah Yogyakarta. Retrieved from http://digilib.unisayogya.ac.id/2590/1/PDF\%2ONASKAH\%2OPUBLIKASI.pdf.

Shahrawat R, Meitei MH, Joon V (2014). Socioeconomic disparity in care seeking behavior for antenatal care and pregnancy complications among Indian women. Health and Population: Perspectives and Issues, 37(1): 27-39. Retrieved from http://medind.nic.in/hab/t14/i1/habt14i1p27.pdf.

Supariasa I (2015). Penilaian Status Gizi.Cetakan II. Jakarta: EGC.

Varney H (2015). Buku Ajar Asuhan Kebidanan. Cetakan II. Jakarta: EGC.

WHO (2018). World Health Organizations: Global Database on Anaemia. Retrieved from https://www.who.int/vmnis/anaemia/en/. 